\title{
Hypocretin-1 Potentiates NMDA Receptor-Mediated Somatodendritic Secretion from Locus Ceruleus Neurons
}

\author{
Xiao-Wei Chen, ${ }^{1,2,3 *}$ Yu Mu, ${ }^{3,5 *}$ Hong-Ping Huang, ${ }^{3}$ Ning Guo, ${ }^{3}$ Bo Zhang, ${ }^{3}$ Shuang-Yi Fan, ${ }^{1}$ Jia-Xiang Xiong, ${ }^{1}$ \\ Shi-Rong Wang, ${ }^{3}$ Wei Xiong, ${ }^{3}$ Wei Huang, ${ }^{1,3}$ Tao Liu, ${ }^{3}$ Liang-Hong Zheng, ${ }^{3}$ Claire Xi Zhang, ${ }^{3}$ Li-Huan Li, ${ }^{5}$ \\ Zheng-Ping Yu, ${ }^{2}$ Zhi-An Hu, ${ }^{1}$ Zhuan Zhou ${ }^{3,4}$ \\ Departments of ${ }^{1}$ Physiology and ${ }^{2}$ Occupational Health, Third Military Medical University, Chongqing 400038, China, ${ }^{3}$ Institute of Molecular Medicine and \\ ${ }^{4}$ State Key Laboratory of Biomembrane Engineering, Peking University, Beijing 100871, China, and ${ }^{5}$ Fuwai Hospital, Peking Union Medical College, Beijing \\ 100005, China
}

Our previous observations showed that several stimuli, including high- $\mathrm{K}^{+}$solution, glutamate, and voltage pulses, induce somatic noradrenaline (NA) secretion from locus ceruleus (LC) neurons. Hypocretin (orexin), a hypothalamic peptide critical for normal wakefulness, has been shown to evoke NA release from the axon terminals of LC neurons. Here, we used amperometry to test the effect of hypocretin-1 (HCRT) on NMDA receptor-mediated somatodendritic release in LC neurons. Either HCRT or NMDA applied alone dosedependently induced somatodendritic secretion. Bath application of HCRT notably potentiated NMDA receptor-mediated somatodendritic NA release. This potentiation was blocked by SB 334867, a selective HCRT receptor (Hcrtr 1) antagonist, or bisindolylmaleimide, a specific protein kinase C (PKC) inhibitor, indicating the involvement of Hcrtr 1 and PKC. Consistent with this, phorbol 12-myristate 13-acetate, a PKC activator, mimicked the HCRT-induced potentiation. Furthermore, HCRT enhanced NMDA-induced intracellular $\mathrm{Ca}^{2+}$ elevation via activation of Hcrtr 1 and PKC, which may contribute to HCRT-potentiated somatodendritic secretion. These results suggest that HCRT modulates LC activity not only by regulating noradrenergic input to its targets, but also by affecting noradrenergic communication in the soma and dendrites.

Key words: hypocretin; locus ceruleus; noradrenaline; NMDA; somatic secretion; amperometry

\section{Introduction}

Hypocretins (orexins) have been implicated in feeding, neuroendocrine homeostasis, autonomic functions, drug addiction, and sleep/wakefulness (Sakurai, 2007). They act on two G-proteincoupled receptors, hypocretin receptors 1 and 2 (Hcrtr 1 and 2), which are differentially expressed throughout the CNS (Sakurai et al., 1998; Marcus et al., 2001). Locus ceruleus (LC) neurons are densely innervated by hypocretinergic-immunoreactive fibers and mainly express Hcrtr 1 but less Hcrtr 2 (Horvath et al., 1999; Marcus et al., 2001). Application of hypocretins has a direct excitatory effect on LC neurons and increases their activity (Hagan et al., 1999; Horvath et al., 1999; Soffin et al., 2002; van den Pol et al., 2002). Furthermore, hypocretins evoke noradrenaline (NA) release from the axonal terminals of LC neurons in the dentate gyrus and cerebral cortex (Hirota et al., 2001; Walling et al., 2004). Vesicles are generally released not only from axon terminals, but also from cell bodies in various cell types. We recently

Received July 26, 2007; revised Jan. 29, 2008; accepted Feb. 7, 2008.

This work was supported by grants from the National Basic Research Program of China (2006CB500800 and G2007CB512100) and the National Natural Science Foundation of China (30728009, 30770788, 30670668, and 30770521) to Z.Z., Z.-A.H., and C.X.Z. We thank Dr. lain C. Bruce for comments on this manuscript.

*X.-W.C. and Y.M. contributed equally to this study.

Correspondence should be addressed to Zhi-An Hu or Zhuan Zhou at the above addresses. E-mail: zhianhu@yahoo.com.cn or zzhou@pku.edu.cn.

D0I:10.1523/JNEUROSCI.4426-07.2008

Copyright $\odot 2008$ Society for Neuroscience $\quad 0270-6474 / 08 / 283202-07 \$ 15.00 / 0$ measured NA secretion from the somata of LC neurons (Huang et al., 2007). Because of these results, combined with the findings that the main typical responses to hypocretin receptor activation include elevation of intracellular calcium concentration $\left(\left[\mathrm{Ca}^{2+}\right]_{\mathrm{i}}\right)$ (Sakurai et al., 1998; van den Pol et al., 1998; Smart et al., 1999), an event essential for somatic release (Jaffe et al., 1998; Huang et al., 2007), we sought to investigate whether hypocretins modulate somatodendritic secretion in LC neurons.

Glutamate, which activates NMDA receptor (NMDAR)mediated neurotransmission, provide the major excitatory input to LC neurons and are involved in many physiological functions (Rasmussen, 1995; Mendiguren and Pineda, 2004). Interactions between hypocretins and glutamate/NMDA have been repeatedly reported. Hypocretins reduce postsynaptic NMDA-induced currents in nucleus accumbens neurons (Martin et al., 2002). In contrast, our earlier data showed that hypocretin-1 (HCRT) and glutamate have a synergistic effect on the excitability of prefrontal cortical neurons (Song et al., 2006). Importantly, in the ventral tegmental area, HCRT potentiates NMDAR-mediated transmission, which is critical for synaptic plasticity (Borgland et al., 2006). Nonetheless, little is known about HCRT-NMDA interactions in LC neurons. In the present study, using amperometry and whole-cell patch-clamp recordings in rat brain slices, we first determined whether HCRT or NMDA induced somatodendritic secretion from LC neurons. Subsequently, we investigated 
A

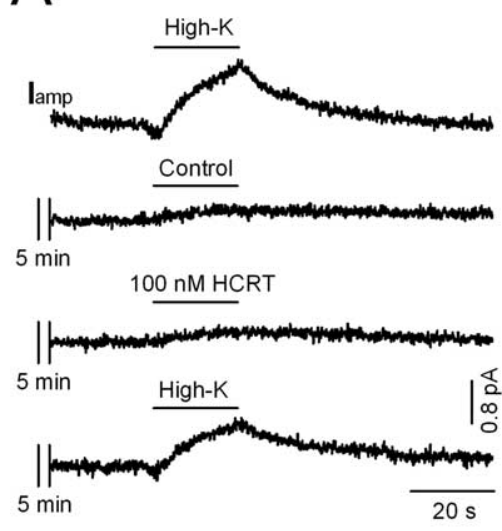

B



C

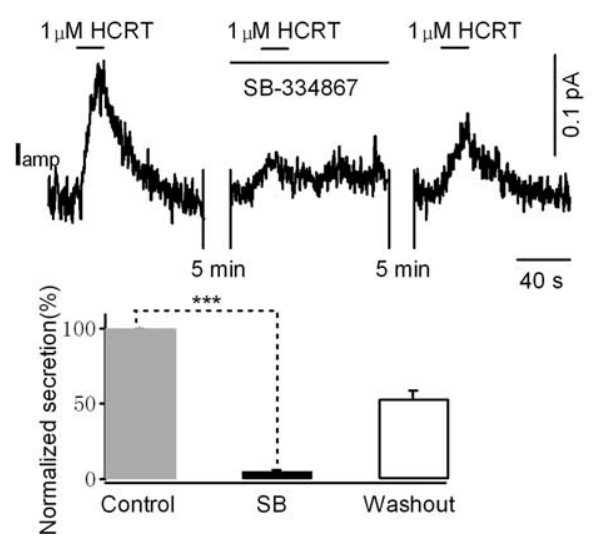

Figure 1. HCRT induces somatodendritic release from $L C$ neurons. $\boldsymbol{A}$, One hundred nanomolar HCRT did not evoke a significant amperometric signal $\left(I_{\text {amp }}\right)$. Normal or high-K ACSF was applied as a negative (Control) or positive control, respectively $(n=6) . \boldsymbol{B}$, In contrast to $100 \mathrm{~nm} \mathrm{HCRT,} 1 \mu \mathrm{M} \mathrm{HCRT} \mathrm{markedly} \mathrm{elicited} \mathrm{secretion}(p<0.01 ; n=9)$. The inset shows that $1 \mu \mathrm{m}$, but not $100 \mathrm{~nm}$ $H C R T$, increased the action potential firing frequency and induced depolarization (11.6 $\pm 1.8 \mathrm{mV} ; n=5)$. C, One micromolar HCRT did not induce an amperometric response in the presence of SB $334867(1 \mu \mathrm{M})$. Inset, Statistical data of the integral of amperometric current (HCRT, $4.7 \pm 0.9 \mathrm{pC} ; \mathrm{HCRT}+\mathrm{SB}, 0.31 \pm 0.06 \mathrm{pC} ;$ Recovery, $3.0 \pm 1.1 \mathrm{pC} ; n=5) . \boldsymbol{D}$, After clearing the extracellular matrix from the soma surface using a cleaning pipette, amperometric spikes induced by high-K or $1 \mu \mathrm{m}$ HCRT were detected ( $n=$ 5). Asterisks indicate single typical amperometric spikes as expanded in insets. ${ }^{*} p<0.05$ and ${ }^{* * *} p<0.0001$ in this and the following figures. Error bars indicate SEM.

whether HCRT affected NMDAR-mediated somatodendritic secretion.

\section{Materials and Methods}

Electrophysiological recordings. Brain slices $(300 \mu \mathrm{m})$ that included LC neurons were obtained from 7- to 14-d-old Sprague Dawley rats as described previously (Huang et al., 2007). LC slices were incubated, and recordings were made at room temperature in artificial CSF (ACSF), which contained the following (in $\mathrm{mM}$ ): $125 \mathrm{NaCl}, 2.5 \mathrm{KCl}, 1.3 \mathrm{MgCl}_{2}, 2.5$ $\mathrm{CaCl}_{2}, 1.25 \mathrm{NaH}_{2} \mathrm{PO}_{4}, 12.5$ glucose, and $25 \mathrm{NaHCO}_{3}, \mathrm{pH} 7.4$ when gassed with $95 \% \mathrm{O}_{2}-5 \% \mathrm{CO}_{2}$. High-K stimulation solution was similar to ACSF, except that $80 \mathrm{~mm} \mathrm{NaCl}$ was replaced by $80 \mathrm{~mm} \mathrm{KCl}$. For whole-cell recordings, the intracellular pipette solution contained the following (in mM): $140 \mathrm{~K}$-gluconate, $0.1 \mathrm{CaCl}_{2}, 2 \mathrm{MgCl}_{2}, 1.1 \mathrm{EGTA}, 10$ HEPES, and $2 \mathrm{Na}_{2} \mathrm{ATP}$, pH 7.25.

Amperometry. Amperometric recordings in LC slices were performed as we previously described (Huang et al., 2007). Carbon fiber electrodes (CFEs; $5 \mu \mathrm{m}$; ProCFE; Dagan, Minneapolis, MN) were used to measure catecholamine release from LC neurons. Amperometry was performed using an EPC9/2 amplifier and Pulse software (HEKA Elektronik, Lambrecht/Pfalz, Germany). Amperometric signals were low-pass filtered at $0.3 \mathrm{kHz}$ and digitized at $1 \mathrm{kHz}$. The CFE surface was positioned in contact with the membrane of a LC neuron, and the close proximity of the electrode surface to the cell surface was confirmed by a slight deformation in the outline of the cell. For comparison of the relative amounts of secretion, baseline corrections were applied to all amperometric currents. We used the integral of amperometric current $\left(\int I_{\mathrm{amp}} \mathrm{d} t\right)$ to quantify the total amount of secretion.

$\left[\mathrm{Ca}^{2+}\right]_{i}$ imaging. For intracellular $\mathrm{Ca}^{2+} \mathrm{im}-$ aging, LC neurons in brain slices were loaded with $15 \mu \mathrm{M}$ fura-2 AM (Invitrogen, Carlsbad, CA) and measured (Kohlmeier et al., 2004; Chen XK et al., 2005). Individual neurons were imaged using a $60 \times$ water-immersion lens with the differential interference contrast (DIC) optics of a fixed-stage upright microscope (BX51 WI; Olympus Optical, Tokyo, Japan). $\mathrm{Ca}^{2+}$ imaging was performed using the TILLvisION Imaging System (TILL Photonics, Martinsried, Germany). We used a ratiometric measure $\left(F_{340} / F_{380}\right)$ by alternating wavelengths of 340 and $380 \mathrm{~nm} .\left[\mathrm{Ca}^{2+}\right]_{\mathrm{i}}$ was measured by $F_{340} /$ $F_{380}$ (Chen XK et al., 2005). Baseline correction was not applied to the fluorescence. All values are presented as mean \pm SEM. Student's $t$ test was used to compare means when appropriate. Differences of $p<0.05$ were considered significant.

\section{Results}

HCRT induces somatodendritic secretion from LC neurons

LC neurons are easily identified by their distinct typical morphological features and electrophysiological properties (Huang et al., 2007). To characterize the effects of hypocretins on somatodendritic secretion, we performed electrochemical recordings with CFEs on the surface of LC neurons in brain slices (supplemental Fig. $1 A$, available at www.jneurosci.org as supplemental material). Local application of high-K solution reliably resulted in an amperometric current $\left(I_{\mathrm{amp}}\right)$ at a holding potential of $780 \mathrm{mV}$, sufficiently high to oxidize catecholamines, but not at $0 \mathrm{mV}$, at which catecholamines cannot be oxidized (supplemental Fig. $1 B$, available at www.jneurosci.org as supplemental material). Because LC neurons mainly express Hcrtr 1, which has a high affinity for HCRT (Sakurai et al., 1998; Marcus et al., 2001), we used only HCRT (orexin A; from Sigma, St. Louis, MO) in all further experiments. Application of $100 \mathrm{~nm} \mathrm{HCRT}$ for $20 \mathrm{~s}$ did not induce an amperometric response, whereas a higher concentration (1 $\mu \mathrm{M}$ ) elicited significant catecholamine release (Fig. $1 A, B$ ). The variation of NA release signals evoked by $1 \mu \mathrm{M}$ HCRT was probably caused by different recording conditions in different cells [i.e., probe and cell conditions (Kawa, 2004; Huang et al., 2007)]. Meanwhile, whole-cell recordings showed that the excitatory action of HCRT on the membrane of LC neurons was also concentration dependent; namely, $1 \mu \mathrm{M}$ but not $100 \mathrm{nM}$ HCRT induced a detectable response (Fig. $1 B$, left inset; supplemental Fig. 2, available at www.jneurosci.org as supplemental material). In addition, HCRT-induced $I_{\text {amp }}$ signal was reversibly inhibited by the selective Hcrtr 1 antagonist SB 334867 ( $1 \mu \mathrm{M}$ ) (Fig. 1C), confirming the role of Hcrtr 1.

The slow amperometric signals presumably reflect vesicles 
from somata or/and processes slightly further away from the electrode, whereas the fast amperometric spikes (quantal events) arise from vesicles released nearby (Koh and Hille, 1997; Huang et al., 2007). Thus, when the CFE surface was positioned in contact with the membrane of a clean cell or when we used a glass pipette to clean off extracellular material overlying the soma before recording (Jaffe et al., 1998; Huang et al., 2007), a barrage of amperometric spikes was detected during $1 \mu \mathrm{M}$ HCRT application and sometimes lasted for 5-10 $\mathrm{s}$ after puffer termination (Fig. $1 D$; supplemental Fig. 3, available at www. jneurosci.org as supplemental material). Occasionally, spontaneous amperometric events occurred before stimulation (Fig. $1 D$; supplemental Fig. 3, available at www.jneurosci.org as supplemental material). Statistically, $1 \mu \mathrm{M}$ HCRT significantly increased the frequency of events from $0.014 \pm 0.002$ events/s to $0.192 \pm$ 0.034 events/s $(p<0.001 ; n=5)$. High-K solution was applied as a positive control (Huang et al., 2007). These results implied that HCRT evoked quantal release detected by the sensor tip on the LC soma. Altogether, we conclude that HCRT evoked catecholamine release within the LC somatodendritic region.

\section{NMDA induces somatodendritic secretion from LC neurons}

We next determined whether activation of NMDA receptors triggered catecholamine release within the LC somatodendritic region. Local application of $100 \mu \mathrm{M}$ NMDA significantly induced $I_{\text {amp }}$ ranging in amplitude from 0.05 to 2.5 pA $(0.69 \pm 0.21 \mathrm{pA} ; n=10)$. In contrast, LC neurons did not show a secretory response to normal ACSF (Fig. $2 A$ ). In addition, both 20 and $1 \mu \mathrm{M}$ NMDA had weaker effects on amperometric responses than that of $100 \mu \mathrm{M}$, suggesting a dose-dependent response (Fig. $2 \mathrm{~B}$ ). Furthermore, pretreatment with the NMDA receptor antagonist APV $(50 \mu \mathrm{M})$ blocked the NMDA-induced secretion from $6.2 \pm 2.8 \mathrm{pC}$ to $0.32 \pm 0.11 \mathrm{pC}(p<0.0001 ; n=$ $5)$ (Fig. $2 B$, inset), confirming the specific action of NMDA receptor activation. These results reveal that NMDA evokes catecholamine secretion within the LC somatodendritic region in a dose-dependent manner.

\section{HCRT potentiates NMDAR-mediated somatodendritic} release from $\mathrm{LC}$ neurons

As described above, HCRT resulted in a concentrationdependent somatodendritic secretion from LC neurons. Next we tested whether HCRT potentiates NMDA-induced secretion. We applied a low dose (100 nM) of HCRT that does not lead to secretion by itself to pretreat the cells before NMDA induction. Puff application of $100 \mu \mathrm{M}$ NMDA evoked a pronounced $I_{\mathrm{amp}}$. This response to NMDA was subsequently enhanced by treatment with $100 \mathrm{nM} \mathrm{HCRT} \mathrm{for} 5 \mathrm{~min}$. After washout of HCRT with normal ACSF for $5 \mathrm{~min}$, the secretory response returned to the control level (Fig. 3A). The temporal effect of HCRT on NMDA- induced amperometric current is clearly shown in Figure $3 B$. After a stable recording was established, an amperometric response was evoked by a $20 \mathrm{~s}$ NMDA application every $5 \mathrm{~min}$ for at least $45 \mathrm{~min}$. Treatment with $100 \mathrm{~nm} \mathrm{HCRT}$ for 5 min resulted in $\sim 40 \%$ potentiation of NMDAR-mediated secretion. This potentiation disappeared after 5 min washout [but see Borgland et al. (2006), where the HCRT effect on NMDA currents lasts for 40 min]. As a control, application of ACSF did not affect the NMDA-induced amperometric response, and compared with the first set of NMDA stimuli, the following stimuli during the 45 min period did not show significant rundown (Fig. 3B, Control). In addition, SB $334867(1 \mu \mathrm{M})$ completely abolished HCRTenhanced NMDA-evoked secretion (Fig. $3 C, F$ ), confirming the prerequisite role of Hcrtr 1. Even in the presence of TTX $(1 \mu \mathrm{M})$, 100 nM HCRT still enhanced the NMDA-induced amperometric response (supplemental Fig. 4, available at www.jneurosci.org as supplemental material), indicating that action potentialindependent release is involved. Moreover, $100 \mathrm{~nm} \mathrm{HCRT} \mathrm{had} \mathrm{no}$ effect on the high- $\mathrm{K}^{+}$-evoked release (supplemental Fig. 5, available at www.jneurosci.org as supplemental material). HCRT (100 $\mathrm{nM}$ ) increased somatic NMDA currents by $30-43 \%$ (supplemental Fig. 6, available at www.jneurosci.org as supplemental material). The NMDA currents were either induced as EPSCs (supplemental Fig. 6A, available at www.jneurosci.org as supplemental material) or measured as somatic whole-cell currents after direct 

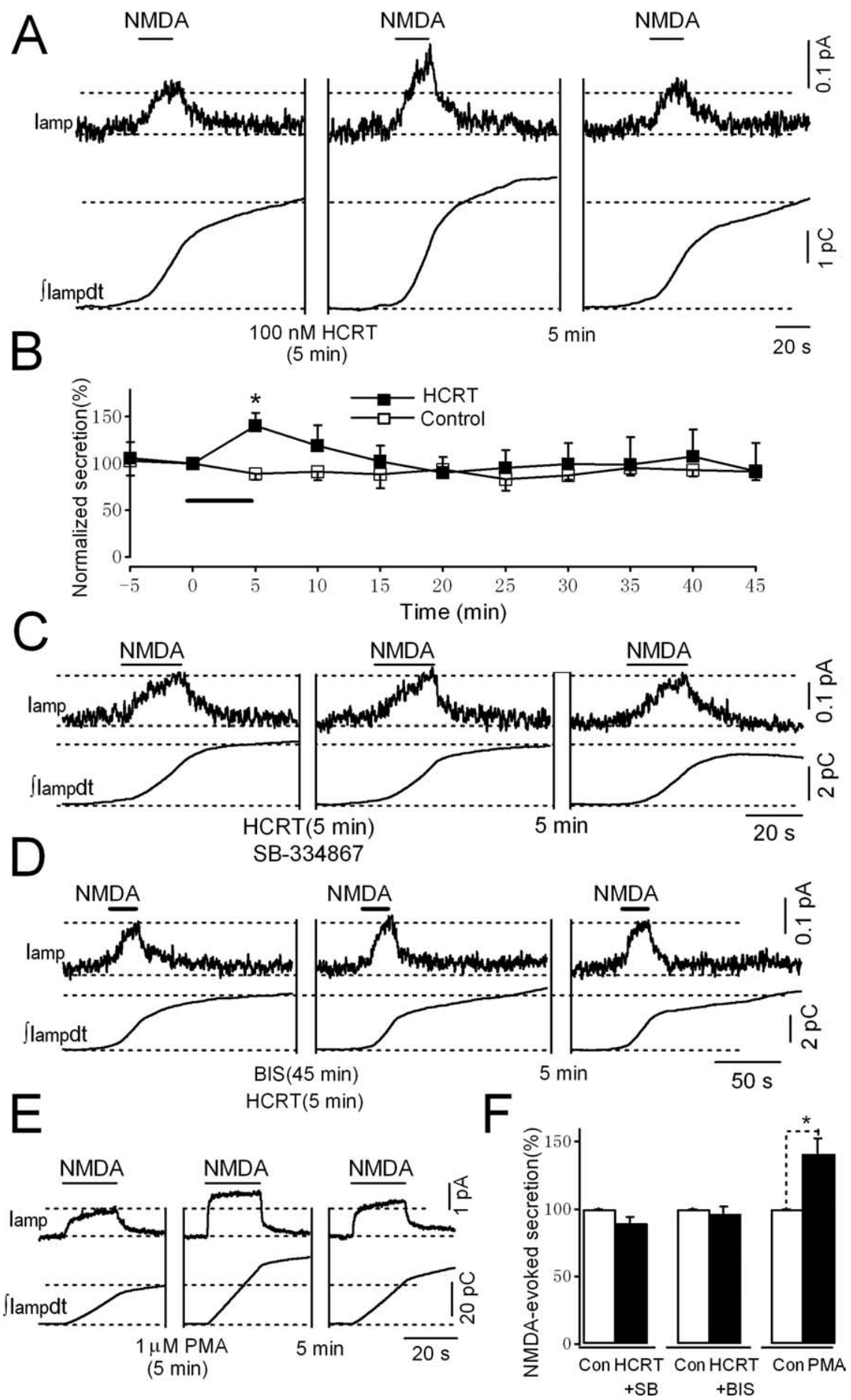

Figure 3. HCRT potentiates NMDAR-mediated somatic secretion through activation of Hcrtr 1 and PKC in LC neurons. $\boldsymbol{A}$, Examples of $I_{\text {amp }}$ (top traces) and integrated current signals $\left(\int I_{\text {amp }} \mathrm{d} t\right.$ ) evoked by $100 \mu \mathrm{m}$ NMDA before and after application of $100 \mathrm{~nm}$ HCRT for 5 min. B, Time course of $100 \mathrm{~nm}$ HCRT or ACSF (Control) action on NMDA-induced secretion. Amperometric signals were elicited every 5 min by $100 \mu \mathrm{M}$ NMDA before and after HCRT treatment $(n=9)$. $C$, In the presence of SB 334867 ( 1 $\mu \mathrm{M}), 100 \mathrm{~nm}$ HCRT did not increase the NMDA-induced secretion. $D$, HCRT-mediated increase in NMDA-induced secretion was blocked by pretreatment with the PKC inhibitor BIS II (1 $\mu \mathrm{M})$ for $45 \mathrm{~min}$. $\boldsymbol{E}$, One micromolar PMA significantly increased NMDA-induced secretion in a manner similar to HCRT. $\boldsymbol{F}$, Bar graph summarizes the statistical data of the normalized amount of secretion in C [ control (Con), 8.2 $\pm 2.1 \mathrm{pC} ; \mathrm{HCRT}+\mathrm{SB}, 7.8 \pm 1.9 \mathrm{pC} ; p>0.05 ; n=5], \boldsymbol{D}$ (Con, 9.8 $\pm 2.7 \mathrm{pC} ; \mathrm{HCRT}+\mathrm{BIS}, 9.3 \pm$ $2.9 \mathrm{pC} ; p>0.05 ; n=5)$, and $\boldsymbol{E}(\mathrm{Con}, 18.0 \pm 6.1 \mathrm{pC} ; \mathrm{PMA}, 27.3 \pm 9.5 \mathrm{pC} ; p<0.05 ; n=4)$.

NMDA application (supplemental Fig. 6B, available at www. jneurosci.org as supplemental material). This is consistent with the findings for dopamine neurons of the ventral tegmental area (Borgland et al., 2006). Thus, NMDA receptors were modulated by HCRT in LC neurons.
The frequency of spontaneous action potentials is $3-5 \mathrm{~Hz}$, which is not sufficient to trigger NA release from LC somata (Huang et al., 2007). However, increasing the AP frequency to $20 \mathrm{~Hz}$ (or higher) triggers NA release. After application of NMDA (5-100 $\mu \mathrm{M})$, AP frequency increased up to $20 \mathrm{~Hz}$ (supplemental Fig. 7, available at www. jneurosci.org as supplemental material), sufficient to trigger somatic NA release (Huang et al., 2007). Therefore, the modulation of NMDA currents by HCRT can also modulate NA release from LC soma via NMDA channels.

Activation of protein kinase $\mathrm{C}$ (PKC) mediates the action of HCRT in different cells (van den Pol et al., 1998; Uramura et al., 2001; Xu et al., 2003; Yang et al., 2003; Kohlmeier et al., 2004; Xia et al., 2005). Thus, we next sought to investigate whether $\mathrm{PKC}$ is involved in HCRT-potentiated NMDA-induced somatodendritic secretion. In the presence of the PKC inhibitor BIS II $(1 \mu \mathrm{M})$, the potentiation of the NMDA-induced secretory response by 100 nM HCRT was completely blocked (Fig. $3 D, F$, available at www.jneurosci.org as supplemental material). Furthermore, 5 min treatment with $1 \mu \mathrm{M}$ phorbol 12myristate 13-acetate (PMA), a membranepermeable agonist of PKC, significantly enhanced the NMDA-evoked amperometric response (Fig. 3E,F, available at www. jneurosci.org as supplemental material), thereby mimicking the effect of HCRT. Together, these results confirm that HCRT potentiates NMDAR-mediated somatodendritic secretion through a PKC-dependent pathway in LC neurons.

\section{HCRT enhances NMDAR-mediated $\left[\mathrm{Ca}^{2+}\right]_{\mathrm{i}}$ increases in LC neurons}

Evidence has accumulated that somatodendritic secretion is $\mathrm{Ca}^{2+}$ dependent in different cells, including LC neurons, substantia nigra neurons, isolated snail neurons, cultured mammalian neurons, astrocytes, and endocrine cells (Dan et al., 1994; Chen et al., 1995; Huang and Neher, 1996; Jaffe et al., 1998; Chen X et al., 2005; Huang et al., 2007). In this study, when we replaced the bath solution with $\mathrm{Ca}^{2+}$-free ACSF containing $1 \mathrm{mM}$ EGTA and $200 \mu \mathrm{M} \mathrm{Cd}^{2+}$ for 30 min, neither $100 \mu \mathrm{M}$ NMDA nor $1 \mu \mathrm{M}$ HCRT induced any amperometric signals (Fig. 4A), confirming that NMDA- or HCRT-evoked somatodendritic secretion is $\mathrm{Ca}^{2+}$ dependent in LC neurons.

We next performed $\mathrm{Ca}^{2+}$ imaging experiments to directly detect changes in the $\left[\mathrm{Ca}^{2+}\right]_{\mathrm{i}}$ of LC neurons loaded with fura-2 AM in brain slices. As shown in Figure $4 B$, the same neuron was imaged by bright-field DIC or fura- 2 fluorescence. HCRT at the lower concentration (100 nM) caused barely 
detectable fluorescence changes. In contrast, $1 \mu \mathrm{M}$ HCRT evoked somatodendritic $\mathrm{Ca}^{2+}$ transients, which is in agreement with previous imaging data from dorsal raphe neurons (Kohlmeier et al., 2004). Subsequently, application of 100 $\mu \mathrm{M}$ NMDA induced a $\left[\mathrm{Ca}^{2+}\right]_{\mathrm{i}}$ increase. After adding $100 \mathrm{~nm}$ HCRT to the bath solution for $5 \mathrm{~min}$, the second puff of the same NMDA solution resulted in a larger $\left[\mathrm{Ca}^{2+}\right]_{\mathrm{i}}$ response, suggesting that HCRT potentiates NMDAR-mediated $\left[\mathrm{Ca}^{2+}\right]_{\mathrm{i}}$ increases (Fig. 4C,F). SB $334867(1 \mu \mathrm{M})$ (Fig. $4 D, F)$ or BIS II $(1 \mu \mathrm{M})$ (Fig. $4 E, F)$ blocked the HCRT potentiation of NMDAR-mediated $\left[\mathrm{Ca}^{2+}\right]_{\mathrm{i}}$ increase, indicating that activation of the Hcrtr 1 receptor and PKC plays a role. These results suggest that the HCRT potentiation of NMDAR-mediated $\left[\mathrm{Ca}^{2+}\right]_{\mathrm{i}}$ elevation contributes to the enhanced somatodendritic secretion in LC neurons. Finally, we assessed the temperature effect on NA release. High-K-induced secretion was larger at $32^{\circ} \mathrm{C}$ versus $22^{\circ} \mathrm{C}$. Comparing high-K-, HCRT-, or NMDA-induced secretion at near-physiological temperatures was qualitatively similar to measurements at room temperature (supplemental Fig. 8, available at www.jneurosci. org as supplemental material).

\section{Discussion}

We recently reported that LC neurons release NA from their somata (Huang et al., 2007). Here, we further found that both HCRT (0.1-1 $\mu \mathrm{M})$ and NMDA (1-100 $\mu \mathrm{M})$ evoked somatodendritic NA secretion from these neurons. HCRT, a neuropeptide secreted by specific neurons in the lateral hypothalamus, is crucial for the regulation of wakefulness (de Lecea et al., 1998; Sakurai et al., 1998; Sakurai, 2007). HCRT-immunoreactive fibers and Hcrtr 1 are present in the LC (Marcus et al., 2001). Several lines of evidence have shown that HCRT excites LC neurons (Hagan et al., 1999; Horvath et al., 1999; Soffin et al., 2002; van den Pol et al., 2002) and induces NA release from their axonal terminals in the cerebral cortex and hippocampus (Hirota et al., 2001; Walling et al., 2004). Our present data demonstrated that HCRT at high concentration $(1 \mu \mathrm{M})$ is a trigger for NA secretion from the somatodendritic region. These results imply that the projection from HCRT neurons to the LC may provide a pathway for HCRT modulation of LC functions, not only by regulating noradrenergic input to its targets (Hirota et al., 2001; Walling et al., 2004), but also by regulating noradrenergic transmission in its somatodendritic region. On the other hand, NMDA-type glutamate receptors are one of the major excitatory regulators of activity in LC neurons (Rasmussen, 1995). The current data demonstrated that NMDA (5-100 $\mu \mathrm{M})$ induced a dose-dependent somatodendritic secretion, which might also represent a pathway for the modulation of LC functions.


SB-334867

$100 \mathrm{~s}$

Figure 4. $\quad \mathrm{HCRT}$ potentiates NMDAR-mediated $\left[\mathrm{Ca}^{2+}\right]_{\mathrm{i}}$ elevation via activation of Hcrtr 1 and PKC in LC neurons. $\boldsymbol{A}$, NMDA- or HCRT-induced secretion was dependent on extracellular $\mathrm{Ca}^{2+}$. Application of $\mathrm{Ca}^{2+}$-free ACSF containing $1 \mathrm{~mm}$ EGTA and $200 \mu \mathrm{M}$ $\mathrm{CdCl}_{2}$ for at least 30 min significantly blocked secretion induced by $100 \mu \mathrm{m} \mathrm{NMDA} \mathrm{(top} \mathrm{traces;} n=4$ ) or $1 \mu \mathrm{m} \mathrm{HCRT} \mathrm{(bottom} \mathrm{traces;}$ $n=5)$. After adding normal ACSF containing $2.5 \mathrm{~mm} \mathrm{Ca}^{2+}$ to the perfusion solution, the evoked amperometric signals recovered. black box over the soma of this neuron indicates the region of interest. Right, One micromolar, but not $100 \mathrm{~nm}, \mathrm{HCRT}$ significantly increased $\left[\mathrm{Ca}^{2+}\right]_{\mathrm{i}}(n=4)$. C, Application of $100 \mathrm{~nm}$ HCRT for 5 min increased the $100 \mu \mathrm{m}$ NMDA-induced calcium response. $\boldsymbol{D}, \boldsymbol{E}$ rizes the statistical data of normalized changes in $F_{340} / F_{380}$ ratios in $\mathrm{C}$ control (Con), $0.026 \pm 0.007$ arbitrary units; HCRT, $0.039 \pm$ $0.009 ; p<0.05 ; n=9), \boldsymbol{D}($ Con, $0.04 \pm 0.01 ; \mathrm{HCRT}+\mathrm{SB}, 0.033 \pm 0.009 ; p>0.05 ; n=5)$ and $\boldsymbol{E}(\mathrm{Con}, 0.02 \pm 0.007 ; \mathrm{HCRT}+\mathrm{BIS}$, $0.017 \pm 0.007 ; p>0.05 ; n=6)$.

HCRT has been shown to affect glutamate/NMDA receptormediated actions in various cell populations (Martin et al., 2002; Borgland et al., 2006; Song et al., 2006). Further, in the present work, we demonstrated that NMDA-mediated secretion in LC neurons was potentiated by a lower concentration of HCRT (100 $\mathrm{nM})$. This may result from HCRT modulation of NMDA receptors rather than the direct effect of HCRT on membrane depolarization, as supported by the following findings: (1) $100 \mathrm{nM}$ HCRT itself had no effect on firing rate, membrane voltage, or $\left[\mathrm{Ca}^{2+}\right]_{\mathrm{i}}$ (Figs. $1 \mathrm{~B}, 4 \mathrm{~B}$ ). (2) $100 \mathrm{~nm}$ HCRT had no effect on high$\mathrm{K}^{+}$-evoked secretion (supplemental Fig. 5, available at www. jneurosci.

org as supplemental material). (3) Like the results from dopamine neurons of the ventral tegmental area (Borgland et al., 2006), we found that $100 \mathrm{~nm}$ HCRT significantly potentiated somatic NMDAR currents (supplemental Fig. 6, available at 
www.jneurosci.org as supplemental material). (4) This hypothesis is consistent with a report that HCRT induces potentiation of NMDA receptor-mediated neurotransmission via a PLC/PKCdependent insertion of NMDA receptors in dopaminergic synapses of the ventral tegmental area (Borgland et al., 2006). Collectively, considering that LC somatodendritic secretion provides a negative feedback via autoreceptors to inhibit LC activity (Huang et al., 2007), HCRT modulation of NMDAR-mediated somatodendritic secretion may reflect a novel pathway for depressing LC hyperactivity-associated opioid withdrawal (Rasmussen, 1995; Mendiguren and Pineda, 2004). Note that although the HCRT-potentiated catecholamine release was measured at CFE sensor touching the soma, it remained possible that some of the evoked signals came from local terminals or dendrites.

Somatic exocytosis is $\mathrm{Ca}^{2+}$ dependent in various cells (Dan et al., 1994; Chen et al., 1995; Huang and Neher, 1996; Chen X et al., 2005; Chen XK et al., 2005). More recently, we found that NA release from the somata of LC neurons is also dependent on $\mathrm{Ca}^{2+}$ entry (Huang et al., 2007). In the present study, $\mathrm{Ca}^{2+}$ imaging data provided evidence that HCRT enhances NMDAR-mediated $\left[\mathrm{Ca}^{2+}\right]_{\mathrm{i}}$ elevation, which may underlie the HCRT potentiation of somatodendritic release. We further revealed a role of Hcrtr 1 and $\mathrm{PKC}$ in the enhanced $\mathrm{Ca}^{2+}$ response. It is well established that PKC is crucial for the action of HCRT (van den Pol et al., 1998; Uramura et al., 2001; Xu et al., 2003; Yang et al., 2003; Kohlmeier et al., 2004; Xia et al., 2005). PKC increases the NMDA channel opening probability and induces delivery of new NMDA receptors to the plasma membrane (Lan et al., 2001). Consistent with this, recent data from ventral tegmental neurons confirm that HCRT stimulates the movement of NMDA receptors to synaptic sites (Borgland et al., 2006). Therefore, these results lead to the hypothesis that the binding of HCRT to Hcrtr 1 on LC neurons activates PKC, thereby enhancing NMDA channel activity either by increasing channel opening probability or by affecting NMDA receptor trafficking. Enhancement of NMDA channel activity subsequently leads to the potentiation of $\mathrm{Ca}^{2+}$ entry through the channels themselves and/or voltage-gated $\mathrm{Ca}^{2+}$ channels activated by the depolarization caused by NMDA (Miyakawa et al., 1992), which may contribute to the relevant augmentation of somatodendritic secretion in LC neurons. However, we cannot exclude the existence of other mechanisms underlying HCRT modulation of the NMDA response, such as a direct Hcrtr 1-NMDA receptor interaction independent of PKC involvement.

\section{References}

Borgland SL, Taha SA, Sarti F, Fields HL, Bonci A (2006) Orexin A in the VTA is critical for the induction of synaptic plasticity and behavioral sensitization to cocaine. Neuron 49:589-601.

Chen G, Gavin PF, Luo G, Ewing AG (1995) Observation and quantitation of exocytosis from the cell body of a fully developed neuron in Planorbis corneus. J Neurosci 15:7747-7755.

Chen X, Wang L, Zhou Y, Zheng LH, Zhou Z (2005) “Kiss-and-run” glutamate secretion in cultured and freshly isolated rat hippocampal astrocytes. J Neurosci 25:9236-9243.

Chen XK, Wang LC, Zhou Y, Cai Q, Prakriya M, Duan KL, Sheng ZH, Lingle C, Zhou Z (2005) Activation of GPCRs modulates quantal size in chromaffin cells through G(betagamma) and PKC. Nat Neurosci 8:1160-1168.

Dan Y, Song HJ, Poo MM (1994) Evoked neuronal secretion of false transmitters. Neuron 13:909-917.

de Lecea L, Kilduff TS, Peyron C, Gao X, Foye PE, Danielson PE, Fukuhara C, Battenberg EL, Gautvik VT, Bartlett II FS, Frankel WN, van den Pol AN, Bloom FE, Gautvik KM, Sutcliffe JG (1998) The hypocretins: hypothalamus-specific peptides with neuroexcitatory activity. Proc Natl Acad Sci USA 95:322-327.

Hagan JJ, Leslie RA, Patel S, Evans ML, Wattam TA, Holmes S, Benham CD, Taylor SG, Routledge C, Hemmati P, Munton RP, Ashmeade TE, Shah AS, Hatcher JP, Hatcher PD, Jones DN, Smith MI, Piper DC, Hunter AJ, Porter RA, et al. (1999) Orexin A activates locus coeruleus cell firing and increases arousal in the rat. Proc Natl Acad Sci USA 96:10911-10916.

Hirota K, Kushikata T, Kudo M, Kudo T, Lambert DG, Matsuki A (2001) Orexin $\mathrm{A}$ and $\mathrm{B}$ evoke noradrenaline release from rat cerebrocortical slices. Br J Pharmacol 134:1461-1466.

Horvath TL, Peyron C, Diano S, Ivanov A, Aston-Jones G, Kilduff TS, van Den Pol AN (1999) Hypocretin (orexin) activation and synaptic innervation of the locus coeruleus noradrenergic system. J Comp Neurol 415:145-159.

Huang HP, Wang SR, Yao W, Zhang C, Zhou Y, Chen XW, Zhang B, Xiong W, Wang LY, Zheng LH, Landry M, Hokfelt T, Xu ZQ, Zhou Z (2007) Long latency of evoked quantal transmitter release from somata of locus coeruleus neurons in rat pontine slices. Proc Natl Acad Sci USA 104:1401-1406.

Huang LY, Neher E (1996) Ca(2+)-dependent exocytosis in the somata of dorsal root ganglion neurons. Neuron 17:135-145.

Jaffe EH, Marty A, Schulte A, Chow RH (1998) Extrasynaptic vesicular transmitter release from the somata of substantia nigra neurons in rat midbrain slices. J Neurosci 18:3548-3553.

Kawa K (2004) Discrete but simultaneous release of adenine nucleotides and serotonin from mouse megakaryocytes as detected with patch- and carbon-fiber electrodes. Am J Physiol Cell Physiol 286:C119-C128.

Koh DS, Hille B (1997) Modulation by neurotransmitters of catecholamine secretion from sympathetic ganglion neurons detected by amperometry. Proc Natl Acad Sci USA 94:1506-1511.

Kohlmeier KA, Inoue T, Leonard CS (2004) Hypocretin/orexin peptide signaling in the ascending arousal system: elevation of intracellular calcium in the mouse dorsal raphe and laterodorsal tegmentum. J Neurophysiol 92:221-235.

Lan JY, Skeberdis VA, Jover T, Grooms SY, Lin Y, Araneda RC, Zheng X, Bennett MV, Zukin RS (2001) Protein kinase C modulates NMDA receptor trafficking and gating. Nat Neurosci 4:382-390.

Marcus JN, Aschkenasi CJ, Lee CE, Chemelli RM, Saper CB, Yanagisawa M, Elmquist JK (2001) Differential expression of orexin receptors 1 and 2 in the rat brain. J Comp Neurol 435:6-25.

Martin G, Fabre V, Siggins GR, de Lecea L (2002) Interaction of the hypocretins with neurotransmitters in the nucleus accumbens. Regul Pept 104:111-117.

Mendiguren A, Pineda J (2004) Cannabinoids enhance N-methyl-Daspartate-induced excitation of locus coeruleus neurons by $\mathrm{CB} 1$ receptors in rat brain slices. Neurosci Lett 363:1-5.

Miyakawa H, Ross WN, Jaffe D, Callaway JC, Lasser-Ross N, Lisman JE, Johnston D (1992) Synaptically activated increases in Ca2 + concentration in hippocampal CA1 pyramidal cells are primarily due to voltagegated Ca2 + channels. Neuron 9:1163-1173.

Rasmussen K (1995) The role of the locus coeruleus and N-methyl-Daspartic acid (NMDA) and AMPA receptors in opiate withdrawal. Neuropsychopharmacology 13:295-300.

Sakurai T (2007) The neural circuit of orexin (hypocretin): maintaining sleep and wakefulness. Nat Rev Neurosci 8:171-181.

Sakurai T, Amemiya A, Ishii M, Matsuzaki I, Chemelli RM, Tanaka H, Williams SC, Richardson JA, Kozlowski GP, Wilson S, Arch JR, Buckingham RE, Haynes AC, Carr SA, Annan RS, McNulty DE, Liu WS, Terrett JA, Elshourbagy NA, Bergsma DJ, et al. (1998) Orexins and orexin receptors: a family of hypothalamic neuropeptides and $\mathrm{G}$ protein-coupled receptors that regulate feeding behavior. Cell 92:573-585.

Smart D, Jerman JC, Brough SJ, Rushton SL, Murdock PR, Jewitt F, Elshourbagy NA, Ellis CE, Middlemiss DN, Brown F (1999) Characterization of recombinant human orexin receptor pharmacology in a Chinese hamster ovary cell-line using FLIPR. Br J Pharmacol 128:1-3.

Soffin EM, Evans ML, Gill CH, Harries MH, Benham CD, Davies CH (2002) SB-334867-A antagonises orexin mediated excitation in the locus coeruleus. Neuropharmacology 42:127-133.

Song CH, Chen XW, Xia JX, Yu ZP, Hu ZA (2006) Modulatory effects of hypocretin-1/orexin-A with glutamate and gamma-aminobutyric acid on freshly isolated pyramidal neurons from the rat prefrontal cortex. Neurosci Lett 399:101-105. 
Uramura K, Funahashi H, Muroya S, Shioda S, Takigawa M, Yada T (2001) Orexin-a activates phospholipase $\mathrm{C}$ - and protein kinase C-mediated $\mathrm{Ca} 2+$ signaling in dopamine neurons of the ventral tegmental area. NeuroReport 12:1885-1889.

van den Pol AN, Gao XB, Obrietan K, Kilduff TS, Belousov AB (1998) Presynaptic and postsynaptic actions and modulation of neuroendocrine neurons by a new hypothalamic peptide, hypocretin/orexin. J Neurosci 18:7962-7971.

van den Pol AN, Ghosh PK, Liu RJ, Li Y, Aghajanian GK, Gao XB (2002) Hypocretin (orexin) enhances neuron activity and cell synchrony in developing mouse GFP-expressing locus coeruleus. J Physiol (Lond) 541:169-185.

Walling SG, Nutt DJ, Lalies MD, Harley CW (2004) Orexin-A infusion in the locus ceruleus triggers norepinephrine (NE) release and NEinduced long-term potentiation in the dentate gyrus. J Neurosci 24:7421-7426.

Xia J, Chen X, Song C, Ye J, Yu Z, Hu Z (2005) Postsynaptic excitation of prefrontal cortical pyramidal neurons by hypocretin-1/orexin A through the inhibition of potassium currents. J Neurosci Res 82:729-736.

Xu R, Roh SG, Gong C, Hernandez M, Ueta Y, Chen C (2003) Orexin-B augments voltage-gated L-type $\mathrm{Ca}(2+)$ current via protein kinase C-mediated signalling pathway in ovine somatotropes. Neuroendocrinology 77:141-152.

Yang B, Samson WK, Ferguson AV (2003) Excitatory effects of orexin-A on nucleus tractus solitarius neurons are mediated by phospholipase $\mathrm{C}$ and protein kinase C. J Neurosci 23:6215-6222. 